H. A. Carpio Ramos, P. A. Carpio Ramos, F. J. García-Peñalvo and J. C. Montes Ninaquispe, "Science, technology, and innovation articulation of local public university with economic and social agents," in Proceedings XI JICV 2021. XI International Conference on Virtual Campus (Salamanca, Spain, September 30th October 1st, 2021), A. García-Holgado, F. J. García-Peñalvo, C. S. González-González, A. Infante-Moro and J. C. Infante-Moro, Eds., USA: IEEE, 2021. doi: 10.1109/

\title{
Science, technology, and innovation articulation of local public university with economic and social
}

\author{
Hilda A. Del Carpio Ramos \\ Escuela de Posgrado, \\ Universidad Nacional \\ Pedro Ruiz Gallo \\ Lambayeque, Perú \\ hdelcarpio@unprg.edu.pe
}

\author{
age \\ Pedro A. Del Carpio Ramo \\ Escuela de Posgrado,
Universidad Nacional \\ Pedro Ruiz Gallo, \\ Lambayeque, Perú \\ pdelcarpio@unprg.edu.pe
}

\begin{abstract}
Within the framework of the increase in investment in science and technology to raise the innovation indicators of the countries, this article presents the need to know the factors that intervene in the process of technology transfer to understand the characteristics of Science, Technology, and Innovation articulation of a local public university with the economic and social agents. Qualitative phenomenological design was used to explore theoretical models and expert opinion. Sample was selected retrospectively and by saturation. Data were processed by categorization and analyzed by triangulation. 20 factors and 5 dimensions were obtained in technology transfer, and three types of articulation. It is concluded that the Science, Technology, and Innovation articulation in a local public university is Type $I$, and that the characterization has been achieved based on the factors that participate in technology transfer.
\end{abstract}

Keywords-Science, Technology, and Innovation (STI), Ecosystem, Technology transfer, Innovation, Local public university, Economic and social agents

\section{INTRODUCTION}

Innovation is important because it promotes economic and social development; For this reason, countries invest significantly to generate it; however, achieving this is not enough, since it must be extended and transferred to the productive and social sectors [1], within a digital transformation framework [2]

Innovation starts with Technology Transfer (TT) from research centers that produce Science, Technology, and Innovation (STI) to economic and social agents (ESA). Countries have a national STI system to support TT; however, the inland areas remain at a low competitive level [3]. This reality forces us to investigate this phenomenon.

Successful results are observed in Germany [4], Italy [5], USA [6], China [7], Australia [8], and Argentina [9]; they use the industry 4.0 model [10]. In Finland, university produces STI, startups and business incubators [11]. In Chile, Colombia, Mexico, and Brazil implemented innovation policies [12]; and Costa Rica uses a STI system [13]. The countries also promote the link between the supply of STI and the demand.

Peru also has a STI system; however, according to the Harvard Growth Lab Economic Complexity Index, it continues below Argentina, Colombia, and Chile [14]; Likewise, there is a disparity in the STI; for example, Lambayeque region spent $0.6 \%$ on research and development, versus the country's capital that spent 54\% [11].

In Peru, the institutions that do the most research are the universities. In the interior of the country, the local public university (LPU) presents limitations to transfer the STI, probably because the articulation between the actors is weak. It is estimated then that, knowing the factors that participate in

\author{
Francisco J. García-Peñalvo \\ GRIAL Research Group, \\ IUCE, \\ Universidad de Salamanca, \\ Salamanca, Spain \\ fgarcia@usal.es
} TT, it is possible to understand the characteristics of the articulation of the STI between a LPU and ESA [3].

In the scientific literature, the TT factors have not been expressly found, hence the following questions were raised: What are the factors of the TT process of an LPU? and what are the characteristics of the articulation of the STI of a LPU with ESA?

Objectives of this research were to identify the factors of the TT process, understand the types of articulation of the STI, and interpret the articulation characteristics of the STI between the LPU and the ESA. The work presents theoretical value because it contributes to science, new categories, factors and types of STI articulation [15].

This paper contains: Introduction, Conceptual Framework, Methodology, Technology Transfer, Characteristics of the STI Articulation in LPU with ESA, and Conclusions.

\section{CONCEPTUal FramewOrK}

Keywords used in this research are defined below.

\section{A. Science, Technology, and Innovation}

STI refers to the development of science, technology and innovation activities that are managed to contribute to the economic and social development of a country [14].

\section{B. Science Technology, and Innovation Ecosystem}

STI ecosystem is a structured social system where different types of actors participate and interact [16] to produce value and innovations [17].

\section{Technological Transfer}

TT refers to the process of transmission of research and technology results, and exploitation rights from one ecosystem to another [18].

\section{Articulation}

Activities of articulation refer to social and cultural life, and to the social action carried out by its actors [11].

\section{E. Innovation}

Innovation refers to the creation or improvement of a method, process, product or service, and its acceptance in the company or market [19]

\section{F. Public Local University}

PLU is a legal person under public law; it is in the interior of the country; and its functions are, teaching, research, and extension [20].

\section{G. Economic and Social Agents}

ESA refers to individuals or organizations involved in economic activities [21] and public and private social actions $[22]$. 


\section{H. Change Management Model}

Model supports organizations to implement the change of management methods and technological research methodology to achieve their objectives [23].

\section{Methodology}

In this work, research was carried out with a qualitative, exploratory, and phenomenological approach to obtain the depth and quality of the information [15].

Sample was intentional, a posteriori and by saturation [15]. It was made up of specialized bibliography; and it was possible to select 15 certified researchers, 5 innovation managers, 3 local and international business consultants, and a representative from the social sector.

Data collection techniques were documentary analysis and in-depth interview [15]. Instruments were the comparative table and question guide, respectively. Guide was applied virtually due to the COVID-19 pandemic [24, 25, 26, 27, 28].

Data processing techniques were organization of data in units and categorization, to obtain TT factors. Factors were validated by experts. Factors were then arranged in a table to obtain the types of articulation. Results were analyzed with the triangulation technique [15].

\section{TECHNOLOGY TRANSFER}

This section presents the TT models, TT factors, and articulation types.

\section{A. Models}

The most representative TT models are presented below,

1) Linear Articulation of Innovation: This model is unidirectional; that is, either focused on supply, or focused on demand [29].

2) Researchers' analysis: This model focuses on developing only the STI offer to commercialize the research results. The elements of analysis are three: Motivators, barriers, and facilitators [30].

3) Development of Productive Ecosystemn: This model focuses on the demand for STI. Seeks that companies are entrepreneurs, raise employment and generate patents for new products. It focuses on the following principles: Granular leadership, enabling resources, international parity, and commitment [11].

4) Innovation Ecosystem: This is based on the third version of the Triple Helix model [31, 32]. It establishes linear links between University, companies, and State; first offers technology, second generates innovation, and third regulates and offers scientific and technological infrastructure [33].

5) Knowledge Integration: This model aims to instruct on TT processes, such as, learning capacity [34], absorption capacity, technical-structural elements [35], elements of knowledge management [36].

6) Dynamic Technology Transfer Model: This model adds to the characteristics of the linear model, negotiation skills, incentives, facilitators, technology surveillance resources, prototype development tools and equipment, etc. [18].
7) Technology Transfer for Competitiveness: The model considers the internal factors of companies, dimensions of technology transfer, and dimensions of competitiveness [37].

8) Entrepreneurial University: Academic entrepreneurship is used to commercialize technology, through the creation of university spin-offs. It requires entrepreneurial skills, intellectual property protection, and government support [38].

\section{B. TT Factors}

Factors identified in the TT models are objective, finality, principles, products, STI offer, STI demand, actors, competence, LPU competence, ESA competence, State competence, investment, process evaluation, results evaluation, articulation mechanisms $[11,18,29,30,31,32$, $33,35,36,37,38]$.

In addition, System of Indicators of scientific and technological capacity [1] provides the TT impact evaluation factor; Change Management model [23] contributes two factors, processes flow chart and procedures; and doctoral work [3] contributes two factors: Diffusion and articulation requirements. According to the change management criteria [23], the factors were categorized into five dimensions (Table I).

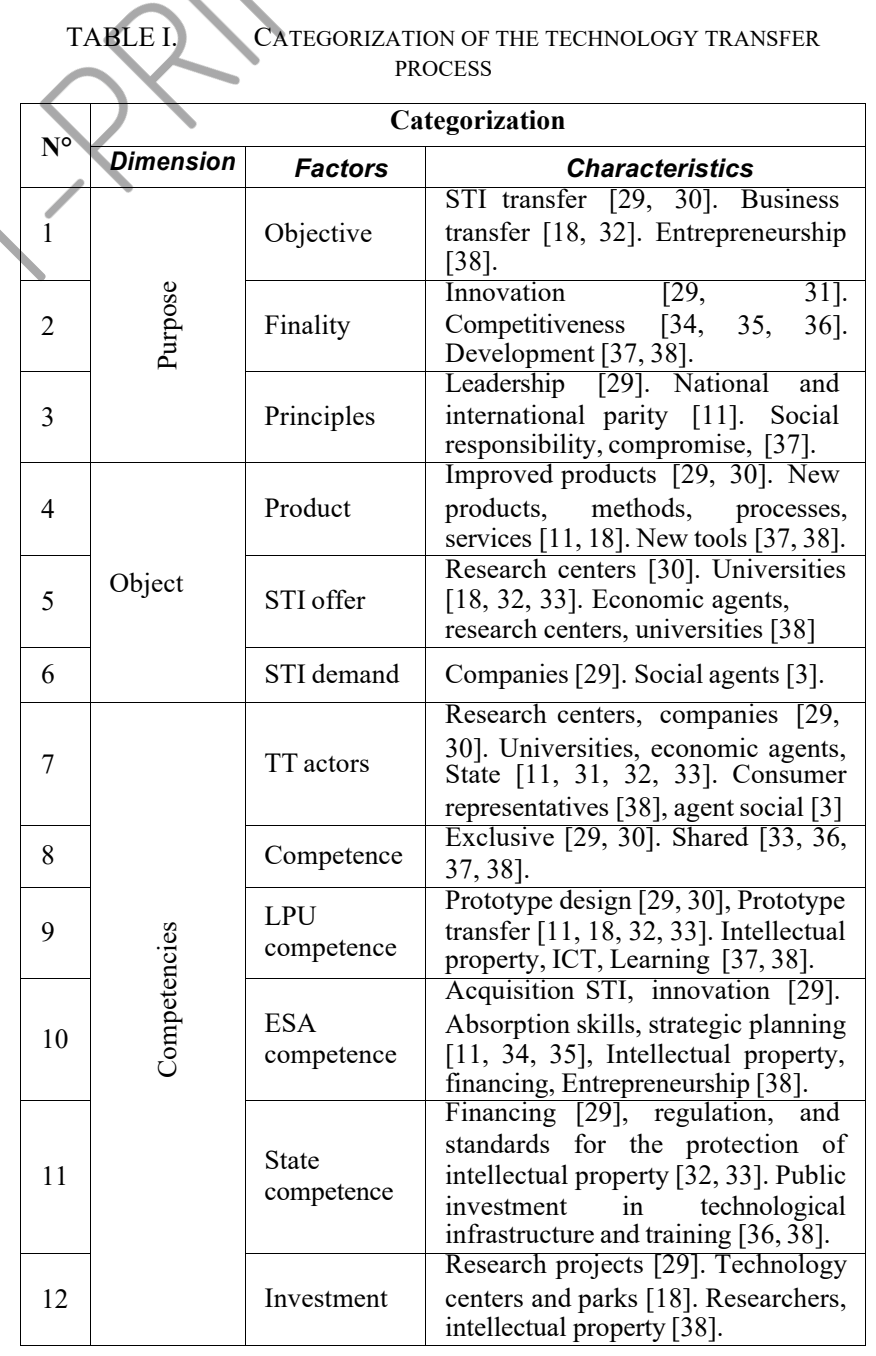




\begin{tabular}{|c|c|c|c|}
\hline \multirow{2}{*}{$\mathbf{N}^{\circ}$} & \multicolumn{3}{|c|}{ Categorization } \\
\hline & Dimension & Factors & Characteristics \\
\hline 13 & 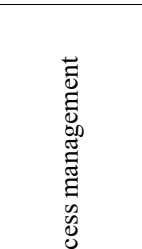 & $\begin{array}{l}\text { Process flow } \\
\text { chart }\end{array}$ & $\begin{array}{l}\text { Announcement, training. Selection } \\
\text { of AES and demands. Application of } \\
\text { intervention and participation } \\
\text { strategy. Dissemination of the } \\
\text { activity and publication of the } \\
\text { opinion of opinion leaders. } \\
\text { Identification of resource providers. } \\
\text { Information systems [23]. }\end{array}$ \\
\hline 14 & & Procedures & $\begin{array}{l}\text { Regulations, manuals, protocols, } \\
\text { quality management, administrative } \\
\text { simplification [23]. }\end{array}$ \\
\hline 15 & & $\begin{array}{l}\text { Process } \\
\text { evaluation }\end{array}$ & $\begin{array}{l}\text { Prototypes }[34,35] \text {, technological } \\
\text { surveillance, system of indicators [1, } \\
38] \text {. }\end{array}$ \\
\hline 16 & & $\begin{array}{l}\text { Results } \\
\text { evaluation }\end{array}$ & $\begin{array}{l}\text { Number of patents, agreements, } \\
\text { contracts }[1,18,37,38] .\end{array}$ \\
\hline 17 & 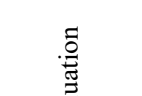 & $\begin{array}{l}\text { Impact } \\
\text { evaluation }\end{array}$ & $\begin{array}{l}\text { Indicators of quality, productive } \\
\text { diversification, competitiveness } \\
\text { index, Poverty, employment [1]. }\end{array}$ \\
\hline 18 & 焉 & $\begin{array}{l}\text { Articulation } \\
\text { mechanism }\end{array}$ & $\begin{array}{l}\text { Agreements, contracts, } \\
\text { administrative simplification [36]. }\end{array}$ \\
\hline 19 & & Diffusion & $\begin{array}{l}\text { Communication, publication, fairs, } \\
\text { promotion, and articulation ICT [3]. }\end{array}$ \\
\hline 20 & & $\begin{array}{l}\text { Articulation } \\
\text { requirements }\end{array}$ & $\begin{array}{l}\text { Professional training, inclusion of } \\
\text { TT subjects, and virtual articulation } \\
\text { office installed in all actors [3]. }\end{array}$ \\
\hline
\end{tabular}

C. Articulation types

Three types of articulation were understood from the characteristics of the TT process factors.

Type I articulation has the following characteristics: The objective is the TT, the purpose is innovation, the principle is leadership, the product is the improvement of the good, the STI supply is the research center, the STI demand is the company, the competence of each is exclusive. In this type, the articulation is minimal, the characteristics are in the first three dimensions of the TT (Table 1) according to the models of TT, Linear [29], Researcher's analysis [30], Development of ecosystems [11], and Innovation [31].

Type II articulation has the following characteristics: The objective is commercial transfer, the purpose is competitiveness, the principle is parity, the product is the creation of new goods, the supply of STI is the university, the demand is the agent economic, the competition of the actors is shared in nature; and the State regulates intellectual property. In this type, the articulation is greater than in Type I, the characteristics are in four dimensions of the TT (Table 1) according to the TT models, Ecosystem development [11], Innovation [32, 33], and Integration of knowledge [34, 35, 36]; and the Change Management model [23].

Type III articulation has the following characteristics: The objective is entrepreneurship, the purpose is development, the principle is social responsibility, and the product is the new tool to create new goods. The actors, university, economic agent, and State can be supply and demand, at the same time. In addition, the State finances the CTI and regulates intellectual property. In this type, the joint is greater than in Type II. The characteristics are in the five dimensions (Table 1) with emphasis on the models Transfer for competitiveness [37], and Entrepreneurial University [38]; of the Change Management model [23]; of the System of Indicators of scientific and technological capacity [1], and of doctoral research [3].

\section{CHARACTERISTICS OF THE STI ARTICULATION IN LPU} WITH ESA

\section{A. Local Public University of Lambayeque}

Lambayeque region, Peru, is in the interior of the country; presents a low level of competitiveness [39] and has 4 private universities and one public.

The LPU was created by Decree Law ${ }^{\circ} 18179$ in March 1970. At present it is governed by University Law 30220, its Statute and Regulation of Organization and Functions of the year 2020. In its structure it has the Vice-Rectorate of Research and with the Innovation and Technology Transfer Directorate [40].

Scientific and technological production focuses on the presentation of final research reports, publication of scientific articles, filing of patent applications and few TT agreements.

\section{B. Opinion of UPL Expert, Researchers and Managers}

LPU expert, researchers and innovation managers opined that, in Lambayeque, the objective of TT is innovation, the purpose is TT, the principle is quality of life, and the product is diversification. LPU offers STI; however, the ESA do not request it because there are no communication bridges. According to them, the articulation between the LPU and the ESA is framed in the models, Lineal [29], Researchers' analysis [30], Development of productive Ecosystems [11], and Innovation Ecosystem [31]; and therefore, the characteristics of the joint are Type I. This result gives content validity to the TT factors.

\section{Opinion of the experts representing ESA}

Experts from the productive and social sectors opined that, in Lambayeque, objective of the TT is innovation, the purpose is competitiveness, the principle is the attention to social and economic problems, and the product is the STI produced by the LPU for ESA. According to the opinion of the experts, the articulation between the LPU and the ESA is framed in the models, Linear [29], Researchers' analysis [30], Development of Ecosystems [11], and Innovation Ecosystem [31]; and therefore, the characteristics of the joint are Type I; which also gives content validity to the TT factors.

\section{CONCLUSIONS}

Twenty factors of the TT process were identified in eight TT models, a management model, an Indicators system, and a doctoral thesis report. The factors were categorized in five dimensions: Purpose, Object, Competences, Management by processes, and Evaluation.

Three types of articulation were included: Type I, with poor articulation between the LPU and the ESA; Type II, of regular articulation; and Type III, highly articulated.

The characteristics of the articulation of the STI in a LPU with the ESA were interpreted as Type I.

The characterization obtained in this work coincides with the reality of the observed phenomenon and, therefore, it can be understood that the characteristics of the STI articulation are obtained from of the TT factors.

It is recommended to continue with the investigation to measure the reliability and stability of the results. 
[1] H. Del Carpio, P. Del Carpio and F. García-Peñalvo, "A system of indicators for assessing scientific and technological capacity at local universities," in 6th International Conference on Technological Ecosystems for Enhancing Multiculturality, TEEM 2018, Salamanca, 2018.

[2] F. J. García-Peñalvo, "Digital Transformation in the Universities: Implications of the COVID-19 Pandemic," Education in the Knowledge Society, vol. 22, no. e25465, 2021.

[3] H. Del Carpio, "Modelo de articulación de la ciencia, tecnología e innovación de la universidad pública con agentes económicos y sociales. Lambayeque, 2021", Inédito.

[4] M. Götz, "Cluster role in industry 4.0 - a pilot study from Germany," Competitiveness Review: An International Business Journal, vol. 31, no. 1, pp. 54-82, 2021.

[5] C. Cimini, A. Boffelli, A. Lagorio, M. Kalchschmidt and R. Pinto, "How do industry 4.0 technologies influence organisational change? An empirical analysis of Italian SMEs," Journal of Manufacturing Technology Management, vol. 32, no. 3, pp. 695-721, 2021.

[6] F. F. Adedoyin, F. V. Bekun, O. M. Driha and D. Balsalobre-Lorente, "The effects of air transportation, energy, ICT and FDI on economic growth in the industry 4.0 era: Evidence from the United States," Technological Forecasting and Social Change, vol. 160, no. 120297, 2020 .

[7] X. Zhou, M. Song and L. Cui, "Driving force for China's economic development under Industry 4.0 and circular economy: Technological innovation or structural change?," Journal of Cleaner Production, vol. 271, no. $122680,2020$.

[8] J. L. Hopkins, "An investigation into emerging industry 4.0 technologies as drivers of supply chain innovation in Australia," Computers in Industry, vol. 125, no. 103323, 2021.

[9] M. M. Formichella, M. V. Alderete and M. Gisela, "New Technologies in Households: Is there an Educational Payoff? Evidence from Argentina," Education in the Knowledge Society, vol. 21, no. 18, 2020

[10] V. Roblek, M. Meško and A. Krapež, "A complex view of Industry 4.0," SAGE Open, vol. 6, no. 2, 2016.

[11] Plataforma VINCULATE, "Marco Conceptual de los Ecosistemas de CTI," Consejo Nacional de Ciencia, Tecnología e Innovación Tecnológica - CONCYTEC, Lima, 2021.

[12] M. Mazzucato and C. Penna, "La era de las misiones. ¿Como abordar los desafíos sociales mediante políticas de innovación orientadas por misiones en América Latina y el Caribe?," Banco Interamericano de Desarrollo, Washington, D. C., 2020.

[13] L. Peralta, "El sistema de innovación para łas mipymes costarricenses: hacia un modelo de articulación," Naciones Unidas, CEPAL, Ciudad de México, 2019.

[14] CONCYTEC, "Innovación, Ciencia y Tecnología para un crecimiento sustentable," I+D+iPerú, no. 1, pp. 1-33, 2021.

[15] R. Hernández-Sampieri and C. Mendoza, Metodología de la investigación: las rutas cuantitativa, cualitativa y mixta, CIudad de México: Mc Graw-Hill Interamericana Editores, S.A. de C. V., 2018.

[16] A. García-Holgado and F. J. García-Peñalvo, "A metamodel proposal for developing learning ecosystems," in Learning and Collaboration Technologies. Novel Learning Ecosystems. 4th International Conference, LCT 2017. Held as Part of HCI International 2017, Vancouver, BC, Canada, July 9-14, 2017. Proceedings, Part I, 2017.

[17] A. García-Holgado and F. J. García-Peñalvo, "Validation of the learning ecosystem metamodel using transformation rules," Future Generation Computer Systems, vol. 91, pp. 300-310, 2019.

[18] M. De Ossa, J. Londoño and A. Valencia-Arias, "Modelo de Transferencia Tecnológica desde la Ingeniería Biomédica: un estudio de caso," Información Tecnológica, vol. 29, no. 1, pp. 83-90, 2018.

[19] M. S. Ramírez-Montoya, "Innovación abierta, interdisciplinaria y colaborativa para formar en sustentablidad energética a través de MOOCs e investigación educativa," Education in the Knowledge Society, vol. 19, no. 4, pp. 11-30, 2018.

[20] Normas Legales, "Ley Universitaria. Ley N 30220," Diario Oficial El Peruano, pp. 2-29, 08 Julio 2014.

[21] S. Rubio, Conceptos e indicadores básicos en economía, Madrid: Escuela Nacional de Sanidad. UNED, 2012.
[22] G. Córdova and M. Romo, Espacio urbano y actores sociales en la ciudad de Chihuahua ¿Mutua reconfiguración?, Tijuana: El Colegio de la frontera Norte, 2015.

[23] H. Del Carpio, P. Del Carpio and F. García-Peñalvo, "Technological research methodology to manage organizational change," in Seventh International Conference on Technological Ecosystems for Enhancing Multiculturality, New York, 2019.

[24] H. A. Del Carpio, P. A. Del Carpio, J. E. Tarrillo, F. J. García-Peñalvo and M. A. Morante, "Online instrument: Perception of virtual learning of the doctorate in the context of COVID-19," in Eighth International Conference on Technological Ecosystems for Enhancing Multiculturality. TEEM 2020, 2020.

[25] H. Fardoun, C. González-Gonzalez, C. A. Collazos and M. Yousef, "Estudio exploratorio en Iberoamérica sobre procesos de enseñanzaaprendizaje y propuesta de evaluación en tiempos de pandemia," Education in the Knowledge Society, vol. 21, no. 17, 2020.

[26] F. J. García-Peñalvo and A. Corell, "La COVID-19: ¿enzima de la transformación digital de la docencia o reflejo de una crisis metodológica y competencial en la educación superior?," Campus Virtuales, vol. 9, no. 2, pp. 83-98, 2020.

[27] F. J. García-Peñalvo, A. Corell, V. Abella-García and M. Grande-dePrado, "Online Assessment in Higher Education in the Time of COVID-19," Education in the Knowledge Society, vol. 21, no. 12, 2020.

[28] F. J. García-Peñalvo, A. Corell, R. Rivero-Ortega, M. J. RodríguezConde and N. Rodríguez-García, "Impact of the COVID-19 on Higher Education: An Experience-Based Approach," in Information Technology Trends for a Global and Interdisciplinary Research Community, F. J. García-Peñalvo, Ed., Hershey, PA: ICI Global, 2021, pp. $1-18$.

[29] G. Rivas and S. Rovira, "Nuevas instituciones para la innovación. Práctica y experiencias en América Latina," Naciones Unidas, CEPAL, Santiago de Chile, 2014.

[30] R. Rodrigo and J. Frega, "Intervenientes do Processo de Transferência Tecnológica em uma," RAC - Revista de Administração Contemporânea, vol. 21, no. 4, pp. 435-457, 2017.

[31] H. Etzkowitz and L. Leydesdorff, Universities and the Global Knowledge Economy. A Triple Helix of University-IndustryGovernment Relations, London: Pinter, 1997.

[32] L. Leydesdorff, "The Triple Helix, Quadruple Helix, ..., and an NTuple of Helices: Explanatory Models for Analyzing the KnowledgeBased Economy?," Journal of the Knowledge Economy, vol. 3, no. 1, pp. 25-35, 2012.

[33] F. J. García-Peñalvo, "The Third Mission," Education in the Knowledge Society, vol. 17, no. 1, pp. 7-18, 2016

[34] F. J. García-Peñalvo, "Modelo de referencia para la enseñanza no presencial en universidades presenciales," Campus Virtuales, vol. 9, no. 1, pp. 41-56, 2020.

[35] Á. Fidalgo-Blanco, M. L. Sein-Echaluce and F. J. García-Peñalvo, "Epistemological and ontological spirals: From individual experience in educational innovation to the organisational knowledge in the university sector," Program: electronic library and information systems, vol. 49, no. 3, pp. 266-288, 2015.

[36] E. Rubio-Royo, S. Cranfield McKay, J. C. Nelson-Santana, R. N. Delgado Rodríguez and A. Occon-Carreras, "Web Knowledge Turbine as a Proposal for Personal and Professional Self-organisation in Complex Times: Application to Higher Education," Journal of Information Technology Research, vol. 11, no. 1, pp. 70-90, 2018.

[37] B. Medina, M. Gasca and L. Camargo, "Modelo de transferencia tecnológica para la competitividad de medianas empresas," Espacios, vol. 40 , no. 42,2019

[38] F. Vega, F. Miranda, J. Pérez and P. Almeida, "La transferencia tecnológica de los académicos en Portugal: intenciones emprendedoras y creación de USO," Espacios, vol. 41, no. 23, pp. 8194, 2020

[39] INEI, "Estadísticas. Índice Temático," 2020. [Online]. Available: https://www1.inei.gob.pe/sistema-estadistico-nacional/.

[40] UNPRG, "Universidad Nacional Pedro Ruiz Gallo," 2021. [Online]. Available: http://www.unprg.edu.pe/univ/portal/licenciamiento. 